Article

\title{
Evaluation of Satellite Rainfall Estimates over the Chinese Mainland
}

\section{Yaxin Qin ${ }^{1}$, Zhuoqi Chen ${ }^{1,3, *}$, Yan Shen ${ }^{2, *}$, Shupeng Zhang ${ }^{1}$ and Runhe Shi ${ }^{3}$}

1 College of Global Change and Earth System Science, Beijing Normal University, Beijing 100875, China; E-Mails: qinyaxin@mail.bnu.edu.cn (Y.Q.); spzhang@bnu.edu.cn (S.Z.)

2 National Meteorological Information Center, China Meteorological Administration, Beijing 100081, China

3 Key Laboratory of Geographic Information Science, East China Normal University, Shanghai 200062, China; E-Mail: shirunhe@gmail.com

* Authors to whom correspondence should be addressed; E-Mails: chenzq@bnu.edu.cn (Z.C.); sheny@cma.gov.cn (Y.S.); Tel.: +86-10-186-1063-3648 (Z.C.).

External Editors: Richard Gloaguen and Prasad S. Thenkabail

Received: 14 July 2014; in revised form: 31 October 2014 / Accepted: 13 November 2014 / Published: 24 November 2014

Abstract: Benefiting from the high spatiotemporal resolution and near-global coverage, satellite-based precipitation products are applied in many research fields. However, the applications of these products may be limited due to lack of information on the uncertainties. To facilitate applications of these products, it is crucial to quantify and document their error characteristics. In this study, four satellite-based precipitation products (TRMM-3B42, TRMM-3B42RT, CMORPH, GSMaP) were evaluated using gauge-based rainfall analysis based on a high-density gauge network throughout the Chinese Mainland during 2003-2006. To quantitatively evaluate satellite-based precipitation products, continuous (e.g., ME, RMSE, CC) and categorical (e.g., POD, FAR) verification statistics were used in this study. The results are as follows: (1) GSMaP and CMORPH underestimated precipitation (about -0.53 and $-0.14 \mathrm{~mm} /$ day, respectively); TRMM-3B42RT overestimated precipitation (about $0.73 \mathrm{~mm} /$ day); TRMM-3B42, which is the only dataset corrected by gauges, had the best estimation of precipitation amongst all four products; (2) GSMaP, CMORPH and TRMM-3B42RT overestimated the frequency of low-intensity rainfall events; TRMM-3B42 underestimated the frequency of low-intensity rainfall events; GSMaP underestimated the frequency of high-intensity rainfall events; TRMM-3B42RT tended to overestimate the 
frequency of high-intensity rainfall events; TRMM-3B42 and CMORPH produced estimations of high-intensity rainfall frequency that best aligned with observations; (3) All four satellite-based precipitation products performed better in summer than in winter. They also had better performance over wet southern region than dry northern or high altitude regions. Overall, this study documented error characteristics of four satellite-based precipitation products over the Chinese Mainland. The results help to understand features of these datasets for users and improve algorithms for algorithm developers in the future.

Keywords: satellite-based precipitation estimates; evaluation; Chinese Mainland

\section{Introduction}

Precipitation is a key component of the planetary water and energy cycle and helps to regulate the surface hydrological fluxes between land and atmosphere. It is also an important input for land surface and hydrological models [1,2]. Accurate measurements of precipitation on regional or global scale are therefore crucial for understanding the climate and hydrological cycle, simulating land surface hydrologic processes and verifying numerical weather prediction [3]. Rain gauges provide a direct physical measurement of precipitation. However, representativeness of a sparse and irregular gauge network is a major problem [4,5]. In addition, it is difficult to provide effective spatial coverage of rainfall over a large area using a low-density gauge network [6]. While weather radars can offer a spatial measure of precipitation, these are prone to inaccuracies due to complex atmospheric conditions, height of the radar beam, beam blocking, variations in the reflectivity-rainfall rate relationships, etc. [7]. Furthermore, weather radars are either sparse or nonexistent in developing countries or ocean areas [8].

Compared with ground based measurements networks (either from rain gauge or weather radar), the possibility of estimating global and near-real-time rainfall from satellite measurements is extremely attractive $[9,10]$. Satellite systems that provide such observations are divided broadly into geostationary (GEO) satellites and low earth orbiting (LEO) satellites [5]. Visible (Vis) and thermal infrared (IR) sensors loaded by GEO satellites permit a high sampling frequency (available every $15 \mathrm{~min}$ ). Vis/IR images provide an excellent depiction of the movement of clouds and weather systems, but their relationship to rain rate is indirect. The main sensors on LEO satellites for precipitation studies are passive microwave (PMW) instruments, which have more direct and physical inference of precipitation. However, they suffer from poor temporal sampling. Many satellite precipitation estimation algorithms have been developed for Vis/IR [11,12] or PMW [13-15] sensors over last two decades.

PMW techniques usually provide more accurate instantaneous estimates of precipitation, while Vis/IR techniques generally provide higher measurements frequency [16]. Therefore, increased attention has been paid to combining measurements of different space-borne sensors to retrieve high quality and resolution precipitation estimates. Early studies include Huffman et al. [17,18] who developed a scheme to combine satellite data of different sensors and built a global precipitation dataset named Global Precipitation Climatology Project (GPCP) at $2.5 \times 2.5^{\circ}$ grid and monthly resolution. More recently, several combination schemes have been developed to build global precipitation estimates with higher spatial $\left(0.25 \times 0.25^{\circ}\right.$ or finer) and temporal (three hourly or shorter) resolutions. These schemes fall 
broadly into two main categories [5]. The first relies upon the PMW to calibrate infrared observations, such as NRL-blended technique [19]. The second category is the advection or morphing schemes, such as the Climate Prediction Center (CPC) morphing technique [20]. Based on advancements in these techniques, several satellite-based global high-resolution precipitation products are now available, including the Precipitation Estimation from Remote Sensing Information using Artificial Neural Network (PERSIANN) [21,22], the PERSIANN Cloud Classification System estimation (PERSIANN-CCS) [23], the Tropical Rainfall Measuring Mission (TRMM) Multisatellite Precipitation Analysis (TMPA) [24,25], the CPC morphing algorithm (CMORPH) [20,26], the Global Satellite Mapping of Precipitation (GSMaP) [27], the Naval Research Laboratory Global Blended Statistic Precipitation Analysis data (NRL-Blend) [19], and so on.

Nevertheless, the inherent shortcoming of satellite-based precipitation products is that they are indirect estimates of rainfall. It is therefore essential to evaluate their accuracy by comparing against gauge observations before application [28,29]. The verification is also beneficial for improvement of the retrieval algorithm [5]. Under the Pilot Evaluation of High Resolution Precipitation Products (PEHRPP) program [30] proposed by the International Precipitation Working Group (IPWG), a number of validation studies have been carried out at different spatial and temporal scales over different regions of the global [16,31-42]. All of these studies suggest that different types of satellite-based precipitation products have variable accuracy in different regions. Therefore, evaluation of the different satellite-based rainfall products over different climatic and geographic regions is very important.

Satellite-based precipitation products have been evaluated over many parts of world. However, evaluation of these satellite-based precipitation products were very limited over the Chinese Mainland. One exception is that of Shen et al., [43], who evaluated six high-resolution satellite-based precipitation products (CMORPH, TRMM, TRMM3B42, PERSIANN, MWCOMB, NRL) using a gauge-based precipitation analysis over China. Their results show that all six satellite-based products are capable to describing spatial distribution and time variation of precipitation. Their work only presents evaluation results for the satellite-based precipitation products at a sub-daily scale. However, error characteristics could be quite different when rainfall rates are temporal accumulation [44]. Other similar validation studies were limited to the specific regions/basins in China [45-49]. Therefore, more detailed exploration of error characteristics for popular satellite-based precipitation products throughout the Chinese Mainland is needed.

In this study, we evaluated four popular satellite-based daily precipitation products over the Chinese Mainland by using a precipitation analysis dataset based on a high-density gauge network. This article consists of five parts: Section 1 is introduction; Section 2 describes the precipitation analysis dataset, satellite-based precipitation products and evaluation statistics; Section 3 documents evaluation results of the satellite-based products; compared with previous studies, our results and methods were discussed in Section 4; and Section 5 gives the conclusions. 


\section{Data and Methods}

\subsection{Gauge-Based Rainfall Analysis}

A gauge-based daily rainfall analysis (China Meteorological Administration gauge-based rainfall analysis, CMA-GRA) was used as a reference dataset to evaluate the satellite-based precipitation products [43]. CMA-GRA was built based on a high-density gauge network that consists of more than 2000 automatic weather stations (Figure 1). An objective technique was used to define CMA-GRA [35,50,51]. CMA-GRA had been used previously in Shen et al.'s work [43].

Figure 1. Distribution of rain gauge stations.

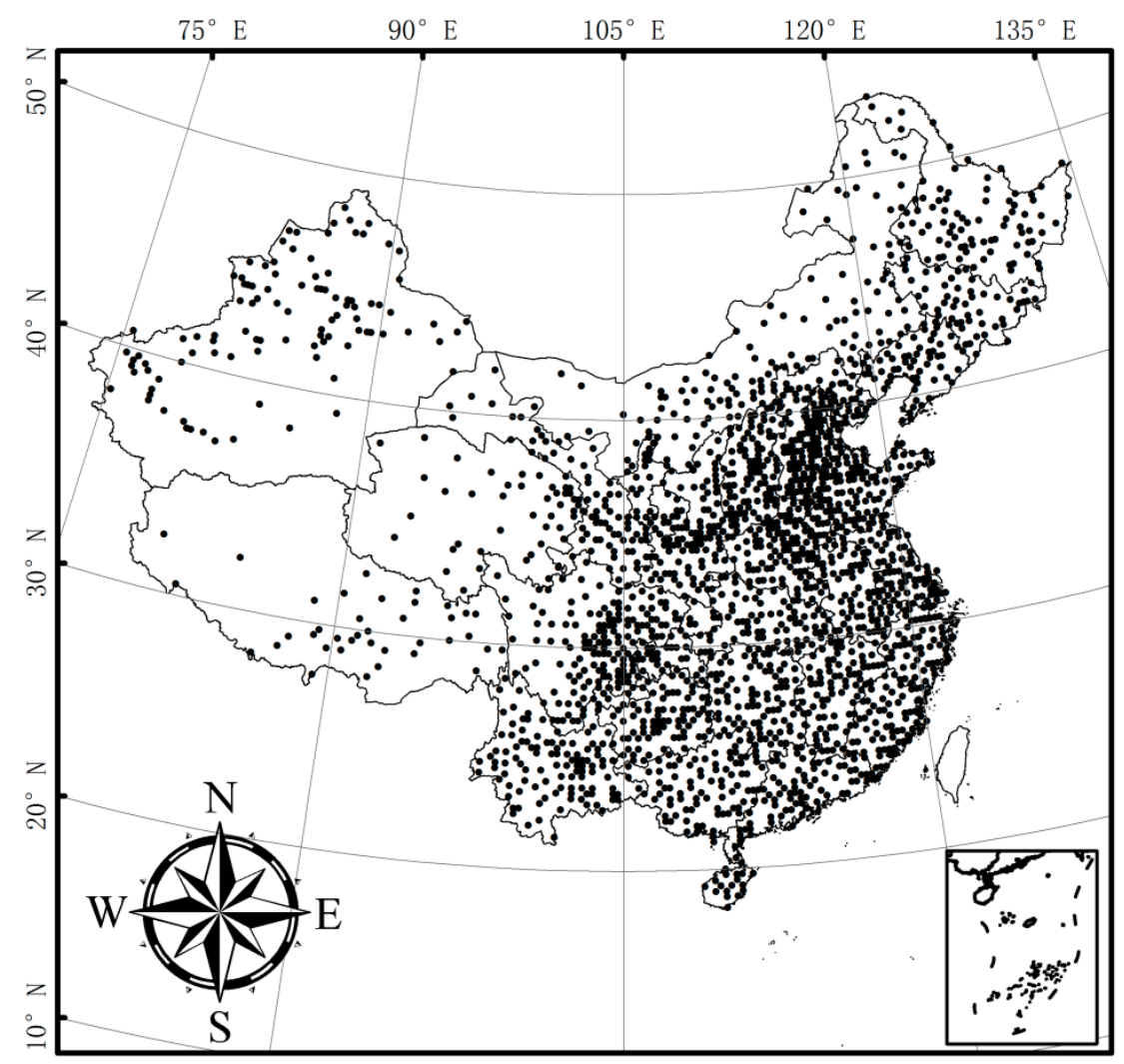

\subsection{Satellite-Based Precipitation Products}

The four satellite-based precipitation datasets used in this study are introduced as follows:

CMORPH is generated by NOAA/CPC $[20,26]$. CMORPH produces global precipitation analyses at very high spatial and temporal resolution. In this technique, IR data are used as a means to transport the microwave-derived precipitation features during periods when microwave data are not available at a location. Furthermore, a time-weighted linear interpolation is used to morph the shape and intensity of the precipitation features [20]. This precipitation is available on $0.07^{\circ}$ Latitude/Longitude $(8 \mathrm{~km}$ at the equator) over the global $\left(60^{\circ} \mathrm{S}-60^{\circ} \mathrm{N}\right)$ in $30 \mathrm{~min}$ temporal resolution from December 1998 to present.

The Global Satellite Mapping of Precipitation (GSMaP) project is sponsored by JST-CREST and is developed by the JAXA Precipitation Measuring Mission (PMM) Science Team [52]. For this study, GSMaP_MVK+ is employed, which used the Kalman filter to compute the estimates of the current 
surface rainfall rates at each $0.1^{\circ}$ pixel of the infrared brightness temperature by the GEO-IR satellites. The rain/no-rain classification scheme and AMSU-B product are also added in. Some literature gives the details of the algorithm $[53,54]$.

The TRMM-3B42 (version 7) three-hourly, $0.25^{\circ} \times 0.25^{\circ}$, in a global belt extending from $50^{\circ} \mathrm{S}$ to $50^{\circ} \mathrm{N}$, is produced by the TRMM project at the National Aeronautics and Space Administration [24]. TRMM-3B42 is the only product corrected by gauge observations in all four datasets. TRMM-3B42RT is a near-real-time version of TRMM-3B42. The difference is that TRMM-3B42RT is not adjusted by gauge observations. The products are developed in four stages: (1) the microwave precipitation estimates are calibrated and combined; (2) infrared precipitation estimates are created using the calibrated microwave precipitation; (3) the microwave and IR estimates are combined; and (4) rescaling to monthly data is applied. Each precipitation field is best interpreted as the precipitation rate effective at the nominal observation time [24,55]. The TRMM-3B42 was corrected by using Global Precipitation Climatology Center (GPCC) full gauge analysis (version 4) and the GPCC monitoring gauge analysis. However, the reference data (CMA-GRA) used in this study was built based on a high-density gauge network that consists of more than 2000 automatic weather stations. Eighty percent gauges in this network are not included in GPCC datasets. It is worthwhile to evaluate TRMM-3B42 over the Chinese Mainland by using this reference dataset.

Four satellite-based precipitation products are demonstrated in Table 1.The data from 2003-2006 was chosen for this study. All datasets were evaluated at a resolution of $0.25^{\circ}$ with daily accumulation.

Table 1. Summary of four satellite precipitation estimates. Four satellite precipitation estimates are CMOPH, GSMaP, TRMM-3B42 and TRMM-3B42RT.

\begin{tabular}{ccccccc}
\hline Name & $\begin{array}{c}\text { Temporal } \\
\text { Resolution }\end{array}$ & $\begin{array}{c}\text { Space } \\
\text { Resolution }\end{array}$ & Domain & $\begin{array}{c}\text { Corrected } \\
\text { by Gauges }\end{array}$ & Period & Ref. \\
\hline CMORPH & $0.5 \mathrm{hr}$ & $0.07^{\circ}$ & $60 \mathrm{~N} \sim 60 \mathrm{~S}$ & No & 1998 -present & {$[20]$} \\
\hline GSMaP & $1 \mathrm{hr}$ & $0.10^{\circ}$ & $60 \mathrm{~N} \sim 60 \mathrm{~S}$ & No & $2002-$ present & {$[27]$} \\
\hline TRMM-3B42 & $3 \mathrm{hr}$ & $0.25^{\circ}$ & $50 \mathrm{~N} \sim 50 \mathrm{~S}$ & Yes & $1998-$ present & {$[24,25]$} \\
\hline TRMM-3B42RT & $3 \mathrm{hr}$ & $0.25^{\circ}$ & $50 \mathrm{~N} \sim 50 \mathrm{~S}$ & No & 1998 -present & {$[24,25]$} \\
\hline
\end{tabular}

\subsection{Validation Method}

To quantitatively evaluate satellite-based precipitation products, continuous (e.g., ME, RMSE, CC) and categorical (e.g., POD, FAR) verification statistics were used in this study. Formulas and a very brief description of these statistics are provided below. The continuous statistics are used to measure the accuracy of variables such as rainfall amount or intensity; the categorical statistics are used to measure the skill in detecting the occurrence of rain events. All statistics have been widely used to evaluate satellite-based precipitation products [16,34].

The continuous verification statistics are mean error (ME), root mean square error (RMSE) and correlation coefficients (CC). The formulas for these statistics are as follows:

$$
M E=\frac{1}{N} \sum_{i=1}^{N}\left(Y_{i}-O_{i}\right)
$$




$$
\begin{gathered}
R M S E=\sqrt{\frac{1}{N} \sum_{i=1}^{N}\left(Y_{i}-O_{i}\right)^{2}} \\
C C=\frac{\sum_{i=1}^{N}\left(Y_{i}-\bar{Y}\right)\left(O_{i}-\bar{O}\right)}{\sqrt{\sum_{i=1}^{N}\left(Y_{i}-\bar{Y}\right)^{2}} \sqrt{\sum_{i=1}^{N}\left(O_{i}-\bar{O}\right)^{2}}}
\end{gathered}
$$

where $\mathrm{Y}_{\mathrm{i}}$ is the estimated value at a point or grid box $\mathrm{i}, \mathrm{O}_{\mathrm{i}}$ is the observed value, and $\mathrm{N}$ is the number of samples.

The categorical verification statistics are probability of detection (POD) and false-alarm ratio (FAR). They can be calculated by following equations:

$$
\begin{gathered}
P O D=\frac{\text { hits }}{\text { hits }+ \text { misses }} \\
F A R=\frac{\text { false alarms }}{\text { hits }+ \text { false alarms }}
\end{gathered}
$$

Hits (misses) mean the satellite based precipitation products detect (miss) rainfall events captured by ground observations. The contingency table for categorical verification statistics and the detailed definition are shown in Table 2. In this study, $1 \mathrm{~mm}$ /day is used as the rain/no rain threshold.

Table 2. Contingency table for comparing rain gauge measurements and satellite precipitation estimates. The rainfall threshold used is $1.0 \mathrm{~mm}$.

\begin{tabular}{lcc}
\hline & Gauge $\geq$ Threshold & Gauge $<$ Threshold \\
\hline Satellite $\geq$ threshold & Hits & False alarms \\
Satellite $<$ threshold & Misses & Correct negatives \\
\hline
\end{tabular}

\section{Results}

\subsection{Evaluation of Satellite-Based Precipitation Products at Grid Scale over the Chinese Mainland}

In this section, CMA-GRA was used to evaluate daily satellite-based precipitation products over the Chinese Mainland for each $0.25^{\circ} \times 0.25^{\circ}$ grid cell that contained at least one rain gauge from 2003 to 2006. These stations are shown in Figure 1. Table 3 presents the validation results. MEs indicated that GSMaP and CMORPH underestimated precipitation by about $0.53 \mathrm{~mm} /$ day and $0.14 \mathrm{~mm} /$ day, respectively. The underestimation of satellite-based precipitation product was also detected by other research [5,31,42,56]. In fact, underestimation of precipitation is a challenge faced by most satellite-based precipitation products [31]. For example, GSMaP product has underestimated precipitation by about $2.3 \mathrm{~mm} /$ day in Colombia [34]. TRMM-3B42RT, however, overestimated precipitation by about $0.73 \mathrm{~mm} /$ day. TRMM-3B42RT has been proved that overestimated precipitation over other regions of world [1,8,34]. Behrangi et al. suggested TRMM-3B42RT had 34.5\% BIAS [8]. ME of TRMM-3B42 was only $-0.02 \mathrm{~mm} /$ day. It exhibited close alignment with CMA-GRA. Due to the correction process against monthly observations, the bias of TRMM-3B42 showed a marked 
improvement over the TRMM-3B42RT and had better correspondence with measurements compared with other satellite-based precipitation products. TRMM-3B42 was consistent with gauge measurements over other regions $[36,40]$. RMSE illustrates the degree of estimates deviating from the gauges. RMSEs of all satellite products ranged from 6 to $7 \mathrm{~mm}$ /day with the exception of TRMM-3B42RT. RMSE of TRMM-3B42RT was about $8.6 \mathrm{~mm} /$ day. The $\mathrm{CC}$ measures the degree of linear association between the estimated and observed distributions [57]. A higher $\mathrm{CC}$ means estimated distribution is closer to observation. The CC value of TRMM-3B42RT, at only 0.55 , also performed the worst of all four products. The CCs of the other three products were about 0.66. The statistics (ME, RMSE, CC) of TRMM-3B42RT and TRMM-3B42 indicate that gauge correction can improve the quality of satellite-based precipitation products.

Table 3.Validation statistics of the four rainfall estimates over Mainland China from 2003 to 2006 .

\begin{tabular}{cccccc}
\hline & $\begin{array}{c}\text { ME } \\
(\mathbf{m m} / \mathbf{d a y})\end{array}$ & $\begin{array}{c}\text { RMSE } \\
(\mathbf{m m} / \mathbf{d a y})\end{array}$ & CC & POD & FAR \\
\hline GSMaP & -0.53 & 6.21 & 0.66 & 0.70 & 0.38 \\
CMORPH & -0.14 & 6.23 & 0.67 & 0.76 & 0.51 \\
TRMM-3B42 & -0.02 & 6.75 & 0.66 & 0.58 & 0.34 \\
TRMM-3B42RT & 0.73 & 8.60 & 0.55 & 0.59 & 0.40 \\
\hline
\end{tabular}

The POD measures the fraction of observed events that were correctly diagnosed. Higher POD value means better performance of the dataset. FAR is fraction of diagnosed events that were actually nonevents. The closer FAR value is to 0 , the better performance of the dataset. POD and FAR values of GSMaP, which were 0.70 and 0.38 , respectively, lie in the middle of all four datasets. CMORPH received the highest POD score in all four datasets but its FAR value was the worst. In the contrast, TRMM-3B42 received the lowest POD score, but its FAR value was the best in all four datasets. POD and FAR scores of TRMM-3B42RT were similar to TRMM-3B42. Gauge correction improved the FAR score of TRMM-3B42RT. But POD score was not improved after gauge correction.

Figure 2 shows the intensity distribution of precipitation events count from each of the four dataset. All grid cells, which contained at least one gauge, were used to count precipitation events from 2003 to 2006 over the Chinese Mainland. The numbers showed in the lower-left corner of Figure 2, such as 0.190 for CMA-GRA, are ratios between rainfall events and total events (both rainfall events and no rainfall events) for every precipitation products. The intensity distributions of the daily number of precipitation events or histograms enable one to better observe the errors at different rainfall rates. Almost all satellite-based precipitation products (GSMaP, CMORPH and TRMM-3B42RT), with the exception of TRMM-3B42, had about $20 \%-50 \%$ more events than CMA-GRA across the range of 1-8 mm/day (low-intensity rainfall events) (Figure 2). TRMM-3B42 had about 10\% fewer events than CMA-GRM across the range of $1-8 \mathrm{~mm} /$ day. The histograms of TRMM-3B42 and CMORPH align well with CMA-GRA in the range of $8-128 \mathrm{~mm} /$ day. TRMM-3B42RT overestimated the number of rainfall events across the range of $8-128 \mathrm{~mm} /$ day, whereas GSMaP had the fewest events among all the datasets across this range. In addition, Figure 2 depicts CMORPH and GSMaP had the most rainfall events when precipitation amount no more than $2 \mathrm{~mm}$ /day. However, reference data (CMA-GRA) and TRMM 
products had the most precipitation events across the range of $2-4 \mathrm{~mm} / \mathrm{day}$. We speculate that the discrepancies at the lower tail of the distributions are related to different algorithms used by different datasets. CMORPH and GSMaP employed morphing technique, which propagates PMW precipitation estimation by using cloud motion vectors derived from IR data, may cause more appearance of low intensity precipitation events.

Figure 2. Intensity distribution of precipitation events calculated from four satellite based precipitation datasets and measurements (CMA-GRA).

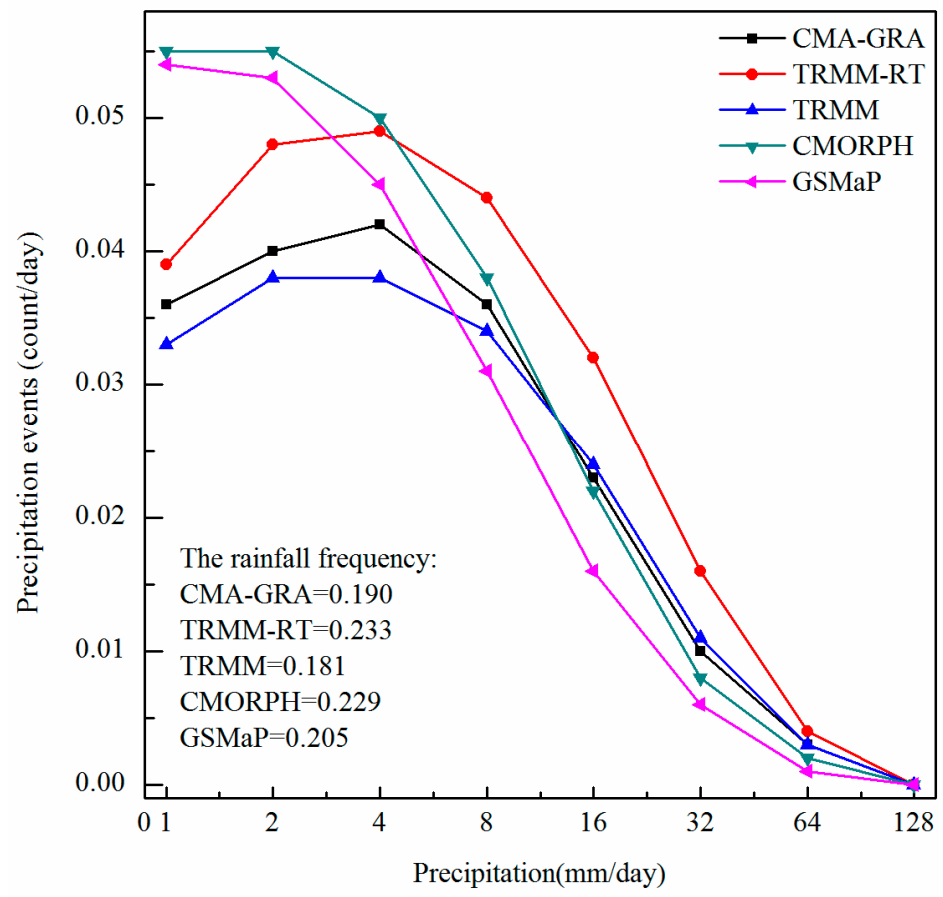

Seasonal variations in the error characteristics of satellite-based precipitation products have been observed over the United States [31]. GSMaP underestimated precipitation in winter and overestimated in summer [31]. Therefore, seasonal variations of the validation statistics were also investigated in this study (Figure 3). All satellite-based precipitation products performed reasonably well in capturing seasonal variations of mean precipitation (Figure 3a). In contrast with its performance in the United States, GSMaP underestimated precipitation all year round over the Chinese Mainland. It underestimated about $70 \%$ in winter and about $15 \%$ in summer (Figure $3 \mathrm{~b}$ ). The mean precipitation of the CMORPH and TRMM-3B42 generally agreed with the CMA-GRA all year around. The TRMM-3B42RT dataset significantly overestimated precipitation each month. RMSEs of all products were similar, with the exception of TRMM-3B42RT. It had the worst RMSE in all four products (Figure 3c). CC, POD and FAR indicated that satellite-based precipitation products performed better in summer than winter. The CCs of all satellite-based precipitation products were higher in summer than in winter (Figure 3d). POD and FAR had significant seasonal variation in all datasets. In winter, the lowest POD value was only 0.2, whereas the highest POD value reached nearly $90 \%$ in summer. It is noted that all satellite products had low POD value in winter. This result is consistent with the findings of previous studies [8,58]. The greater occurrence of low intensity precipitation with weak emissivity signal may cause retrieval algorithms failed to detect precipitation in winter [5]. Sorooshian et al., [59] also pointed out that 
different performance in warm or cold season is one of the limitations of current satellite-based precipitation datasets. The worst FAR values were observed in winter and the best FAR values were observed in summer. Complex background emissivity from cold surface and ice cover in winter may be identified as rain, which could make false precipitation events increased [60,61]. Therefore, satellite-based precipitation products performed better in summer than in winter over the Chinese Mainland. These findings echo work of Kidd et al. [5], who found the satellite products showed a seasonal cycle with relatively good results during summer but relatively poor during winter. AghaKouchak also highlighted the systematic error was remarkably higher during winter over the entire conterminous United States [62]. Poor performance of satellite-based precipitation products during winter could be attributed to cold surface backgrounds emissivity affecting the PMW retrievals or a greater occurrence of low intensity precipitation $[5,59]$.

Figure 3. Seasonal variations of validation statistics. (a) Mean precipitation ( $\mathrm{mm} /$ day); (b) ratio between satellite products and observations (\%); (c) RMSE (mm/day); (d) Correlation coefficients; (e) POD and (f) FAR.
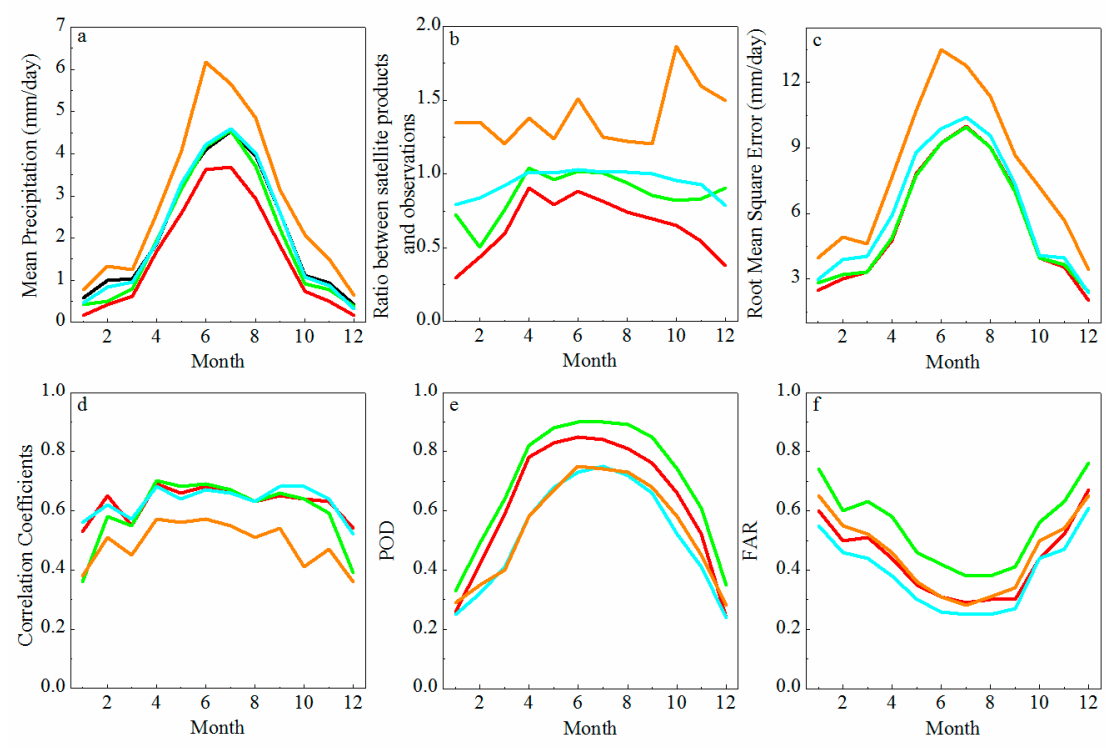

\subsection{Evaluation of Satellite-Based Precipitation Products over the Contiguous Chinese Mainland}

The satellite-based precipitation products had been compared to CMA-GRA over the contiguous Chinese Mainland for the four years period from 2003 to 2006. In order to examine ability of capturing the rainfall spatial patterns of satellite-based precipitation products, snapshots of precipitation patterns for two arbitrary days were selected to compare with corresponding reference data. Figure 4 shows snapshots of precipitation patterns for an arbitrary winter day (12 January 2005) for the CMA-GRA and the four satellite-based precipitation datasets. There were two precipitation systems detected (Figure 4a), one over southern China and the other over central and western China. All satellite-based precipitation products captured the precipitation system in southern China. However, only CMORPH product captured the precipitation system over central and western China. It also noted no-rain events as rain events over the plains of northern China. This result indicated that CMORPH trends to identify more 
rain events than other datasets. GSMaP, TRMM-3B42 and TRMM-3B42RT readily captured the heavy precipitation system in southern China. However, they missed a considerable part of the precipitation area at high latitudes $\left(>40^{\circ} \mathrm{N}\right)$ and high altitudes (e.g., the Qinghai-Tibet Plateau). In addition, obvious underestimation of precipitation was detected in GSMaP and CMORPH. Figure 5 shows snapshots of precipitation patterns for an arbitrary summer day (1 July 2005) for CMA-GRA and the four satellite-based precipitation datasets. The spatial patterns of precipitation systems observed by all datasets aligned with observations, and were notably more in agreement than in winter.

Figure 4. Snapshots of daily precipitation patterns on an arbitrary winter day (12 January 2005) for (a) CMA, (b) GSMaP, (c) CMORPH, (d) TRMM 3B42 and (e) TRMM 3B42RT. Units are $\mathrm{mm} /$ day.
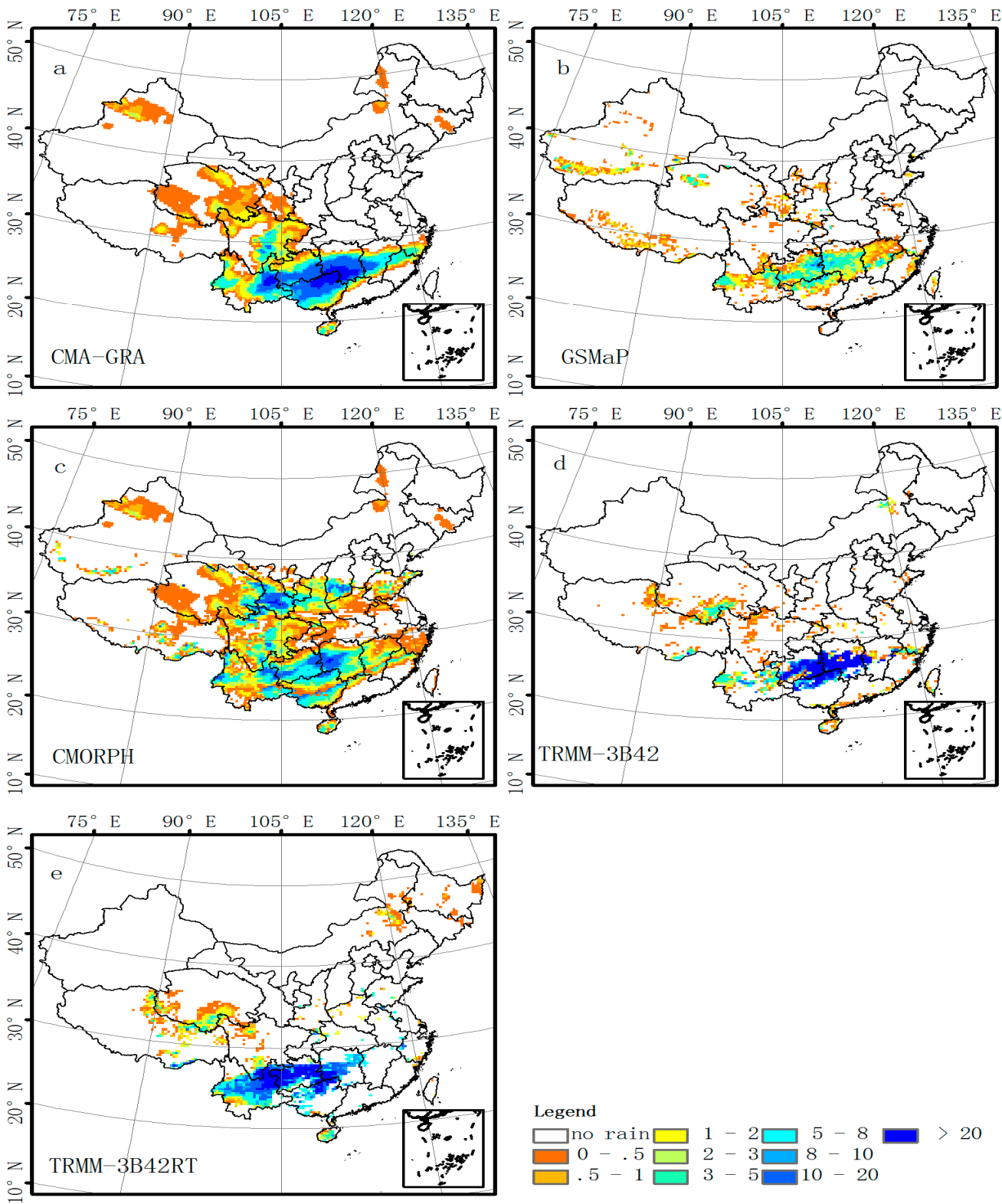
Figure 5. Snapshots of daily precipitation patterns on an arbitrary summer day (1 July 2005) for (a) CMA, (b) GSMaP, (c) CMORPH, (d) TRMM 3B42 and (e) TRMM 3B42RT. Units are mm/day.
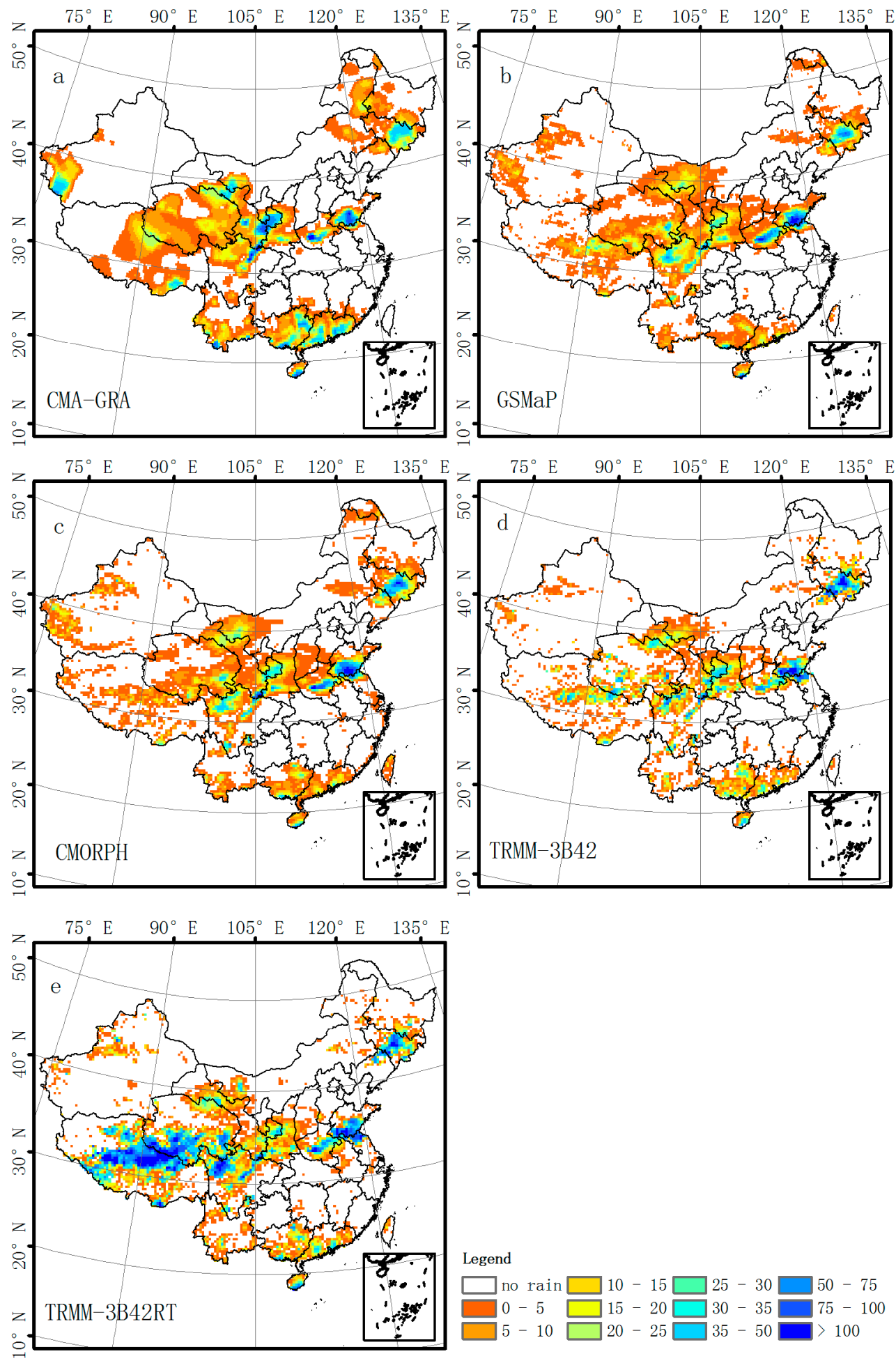

Figure 6 shows the spatial distribution of the four years mean precipitation based on daily gauge analysis and the satellite-based precipitation products. The precipitation distribution over Mainland China was characterized by a southeast-to-northwest decrease in the mean intensity of daily gauge-based analysis data. All satellite-based precipitation products depicted this spatial pattern. However, there was 
an obvious underestimation over southern and southeastern portions of China by GSMaP and CMORPH, where landfall of typhoons and annual migration of the monsoon (Mei-Yu) introduces abundant fresh water. The heavy rainfall may cause signal attenuation of PWM sensor, which may cause underestimation in satellite-based precipitation products. AghaKouchak and Mehran [44,58] also found that satellite-based precipitation products lose their accuracy as precipitation threshold increases over continues of United States. GSMaP and CMORPH tended to underestimate the annual precipitation by about $1-3 \mathrm{~mm} /$ day in these regions. The overestimation is detected in TRMM-3B42RT and GSMaP over arid and semiarid inland regions in the northwestern of China. Many other studies also detected that satellite-based precipitation estimates trend to overestimate precipitation in arid and semiarid regions $[37,40]$. A possible explanation for these overestimations is that raindrops may evaporate before reaching the surface [63]. Therefore, satellite-based precipitation estimates led to overestimation in arid and semiarid regions, but underestimated precipitation in humid regions over the Chinese Mainland. Sorooshian et al. [59] also emphasized that error characteristics of satellite-based precipitation estimates should be investigated in detail over different climate regions. Due to the gauge correction, TRMM-3B42 exhibited close alignment with CMA-GRA over the Chinese Mainland. Figure 7 illustrates the spatial distribution of RMSE between CMA-GRA and satellite-based precipitation estimates. All datasets had similar distribution of RMSE. A large (small) RMSE associated with high (low) intensity of precipitation appeared in southeastern (northwestern) China. AghaKouchak et al. [62] also highlighted that the systematic biases of satellite precipitation were proportional to the rain rate magnitude. Compared to other three precipitation datasets, TRMM-3B42RT had a large RMSE over the Qinghai-Tibet Plateau. Figure 8 shows the spatial distribution of CC between CMA-GRA and satellite-based precipitation products. The CCs of all products are good over most regions of China. Serial correlation coefficient reached 0.7 or higher over southeastern China, and less than 0.2 over most region of northwest. Values of POD and FAR are shown in Figures 9 and 10. PODs of satellite-based precipitation products ranged from 0.5 to 0.9 over the Chinese mainland. The highest POD reached $90 \%$ in the center of the Chinese mainland; FAR ranged from 0.1 to 0.7 with the lowest reaching less than $10 \%$ in southeastern China. The worst POD and FAR values were detected over western of China. These results confirmed conclusion draw by Nasrollahi et al. and AghaKouchak et al. [61,62] Both of these two studies indicated high systematic and FAR value could be related to altitude effect in mountain regions.

All statistics indicate that the performance of the four satellite-based precipitation products over southeastern and wet region was better than in eastern Tibet and most of the regions in northwestern arid and semiarid regions of the Chinese Mainland. The results reinforce the findings of earlier studies. The previous studies presented $[5,59,64]$ that retrieval results were related to precipitation type and intensities. In the southeastern of the Chinese Mainland with a warm and tropical climate, the precipitation type is almost always convective. Satellite-based precipitation estimates tend to demonstrate better estimation of CC, POD and FAR and underestimate precipitation. Across the eastern Tibet and most of the regions in northwestern arid and semiarid regions, the rainfall type is almost always stratiform. Satellite-based precipitation estimates tend to demonstrate worse estimation of CC, POD and FAR and overestimate precipitation. Another possible reason that caused the satellite-based precipitation to have better performance over southeastern of the Chinese Mainland than the Qinghai-Tibet Plateau is the elevation effect. Emissivity signal from lower surface temperature at high-altitude regions may be identified as rain $[60,61]$. In other hand, satellite-based precipitation estimates may miss warm and 
orographic rainfall in mountainous regions [65]. Therefore, it is necessary to improve quality of precipitation estimates in high altitude or mountain regions in future [59].

Figure 6. Distribution of daily mean precipitation over the Chinese Mainland from 2003 to 2006. Units are mm/day. (a) CMA, (b) GSMaP, (c) CMORPH, (d) TRMM 3B42 and (e) TRMM 3B42RT.
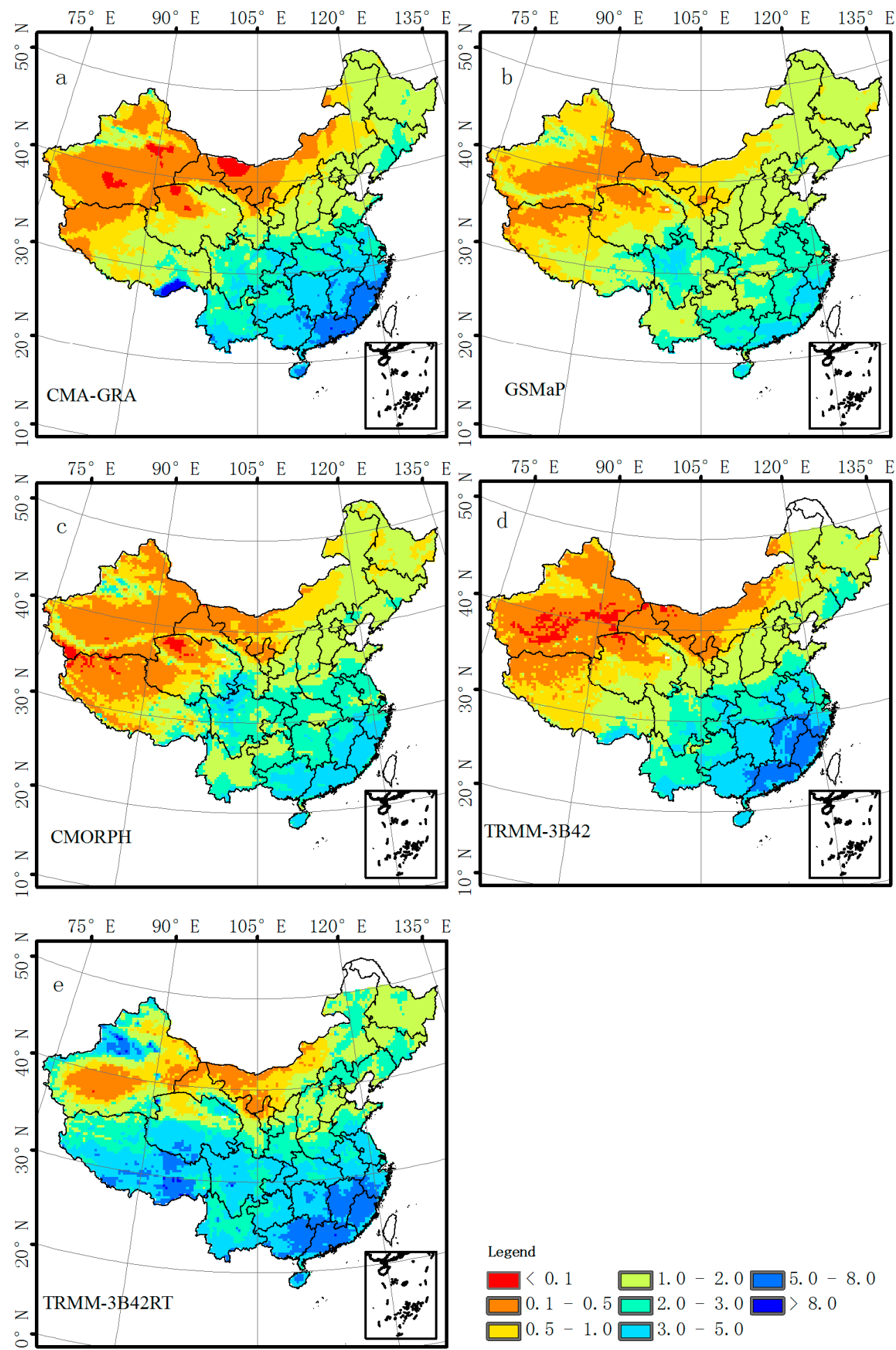
Figure 7. Distribution of RMSE over the Chinese Mainland from 2003 to 2006. (a) GSMaP, (b) CMORPH, (c) TRMM 3B42 and (d) TRMM 3B42RT.
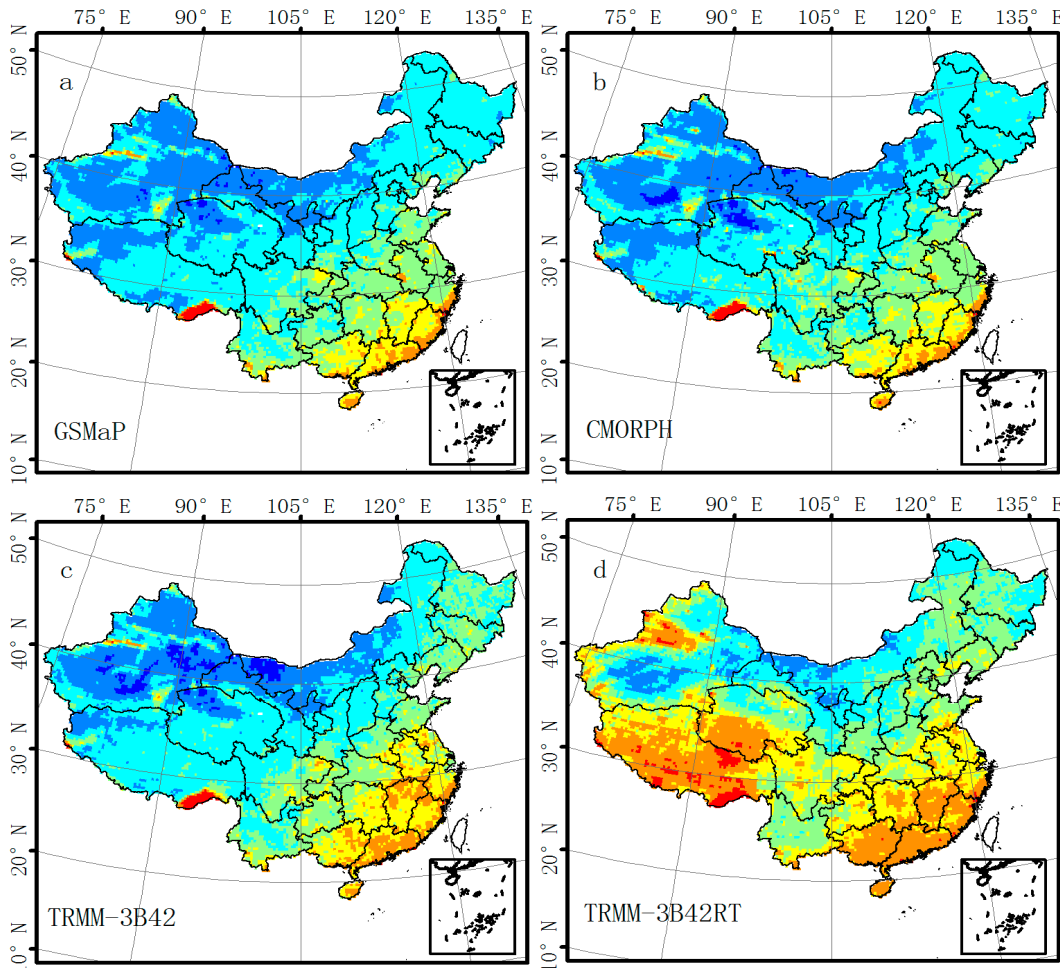

Legend

Figure 8. Distribution of correlation coefficients over the Chinese Mainland from 2003 to 2006. (a) GSMaP, (b) CMORPH, (c) TRMM 3B42 and (d) TRMM 3B42RT.
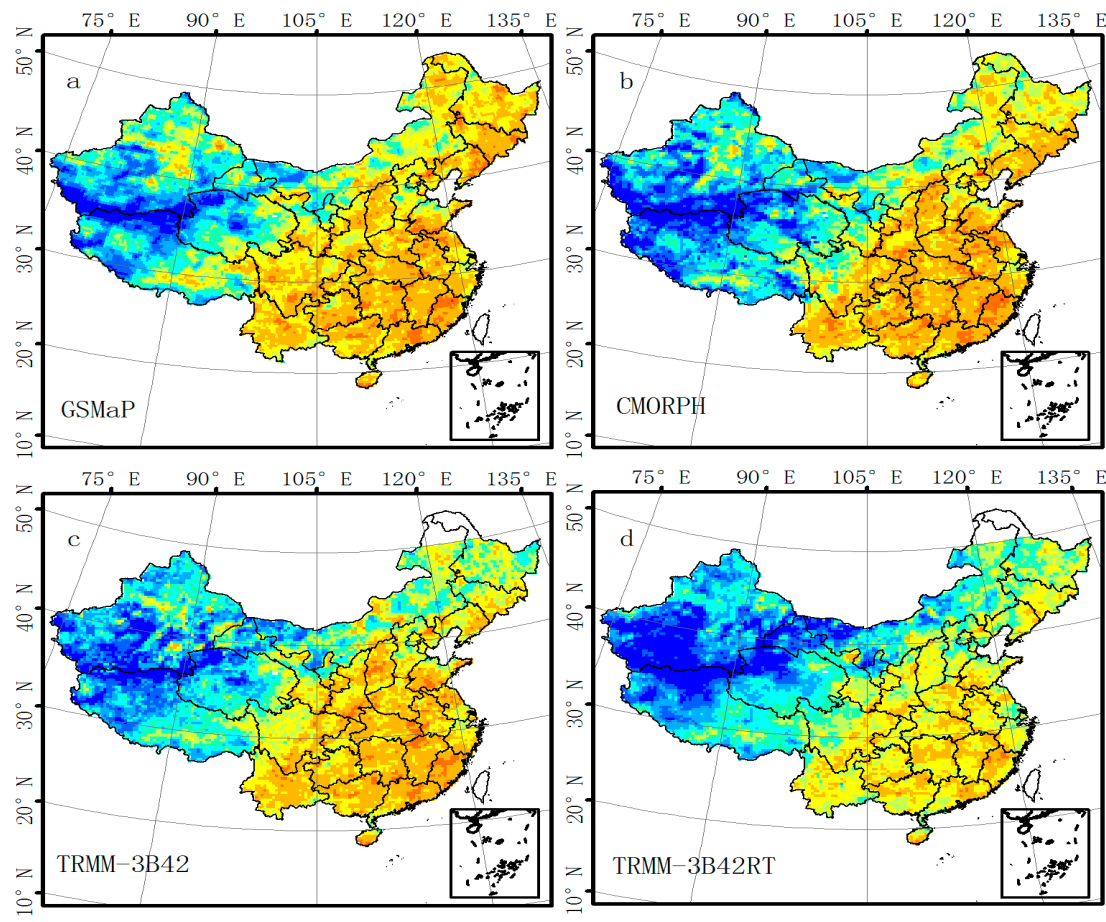

Legend
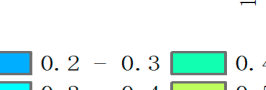

o. $1-0.2$ 
Figure 9. Distribution of POD over the Chinese Mainland from 2003 to 2006. (a) GSMaP, (b) CMORPH, (c) TRMM 3B42 and (d) TRMM 3B42RT.
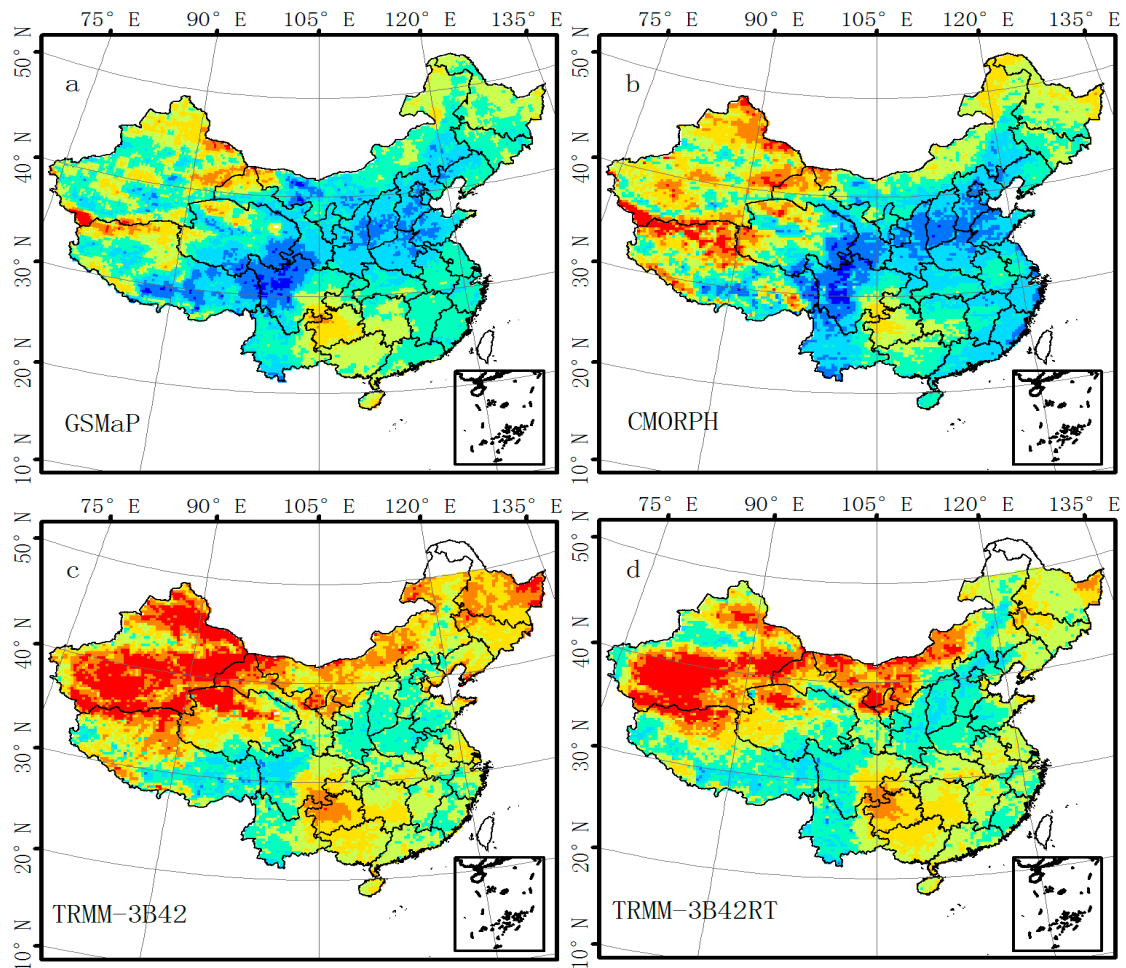

Legend

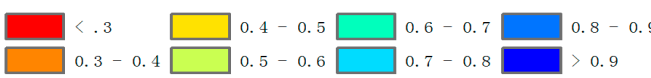

Figure 10. Distribution of FAR over the Chinese Mainland from 2003 to 2006. (a) GSMaP, (b) CMORPH, (c) TRMM 3B42 and (d) TRMM 3B42RT.
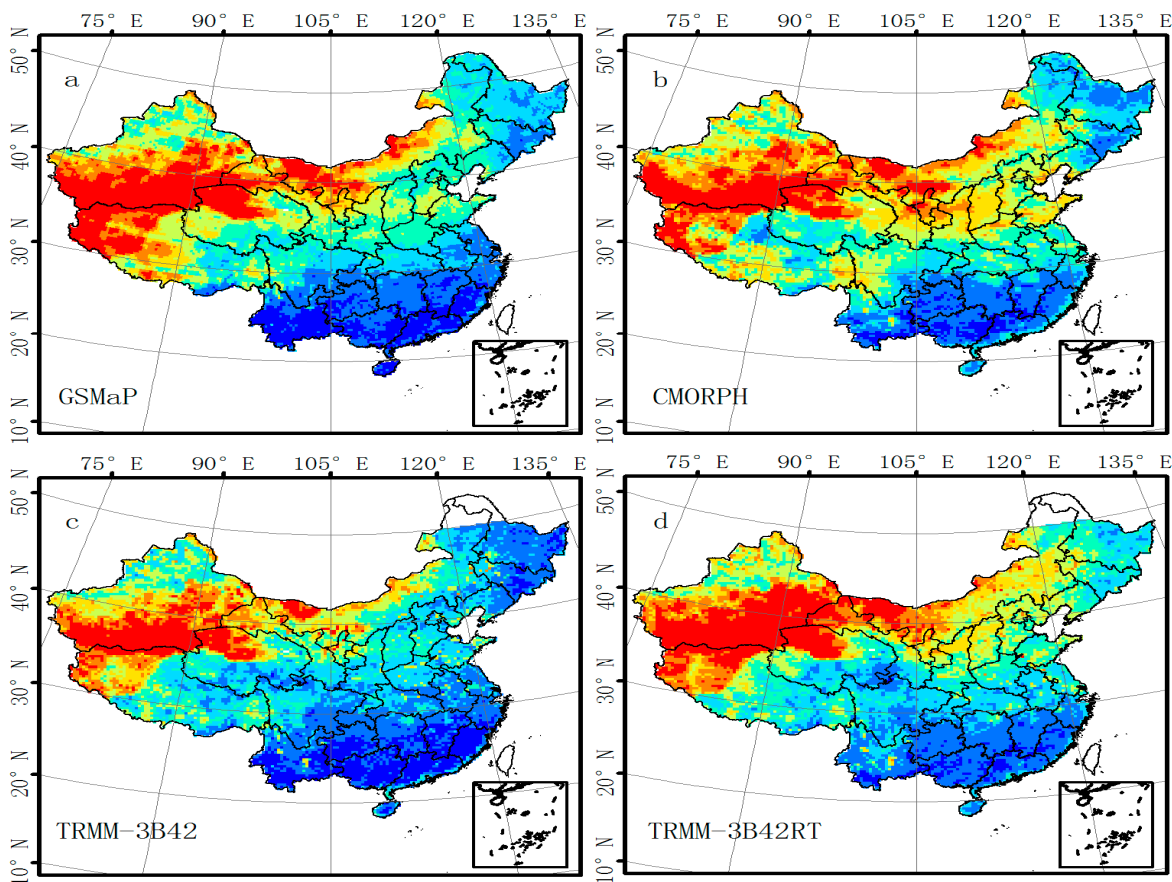

Legend 


\subsection{Evaluation of Satellite-Based Precipitation Products over Mountain and Lowland Regions in the} Chinese Mainland

As shown in the Section 3.2, the accuracy of the satellite-based precipitation products varied in different region over the Chinese Mainland. Many studies indicated complex topography might significantly influence quality of satellite-based precipitation estimates [66,67]. To assess the impact of orographic effects on the performance of satellite-based precipitation products, validation statistics were, respectively, calculated over mountain and lowland regions in the Chinese Mainland (Table 4). Altitudes of mountain (lowland) regions are higher (lower) than $3000 \mathrm{~m}$. GSMaP underestimated precipitation by about $0.99(33 \%)$ and $0.15(10 \%) \mathrm{mm} /$ day over lowland and mountain regions, respectively. $\mathrm{CC}$ indicated GSMaP performed better over lowland than mountain regions. Although GSMaP had a higher POD score in mountain regions than lowland regions, FAR of GSMaP score in mountains regions was worse than in lowland regions. CMORPH underestimated precipitation by about $0.5(-17 \%)$ and overestimated precipitation by about $0.2(12 \%)$. CC, POD and FAR of CMORPH illustrated that CMORPH had better performance in lowland regions than mountain regions. ME of TRMM-3B42 exhibited close consistent with observations both in lowland and mountain regions. TRMM-3B42RT overestimated precipitation by about $0.35(12 \%)$ and $1.62(100 \%) \mathrm{mm} /$ day over lowland and mountain regions, respectively. ME, CC, POD and FAR of TRMM-3B42 and 3B42RT indicated that gauge correction can improve the quality of satellite-based precipitation products both in lowland and mountain regions.

Table 4. Validation statistics of the four rainfall estimates over mountain and lowland regions in the Chinese Mainland from 2003 to 2006.

\begin{tabular}{cccccc}
\hline & $\begin{array}{c}\text { ME } \\
(\mathbf{m m} / \mathbf{d a y})\end{array}$ & $\begin{array}{c}\text { RE } \\
\mathbf{( \% )}\end{array}$ & $\mathbf{C C}$ & POD & FAR \\
\hline $\begin{array}{c}\text { GSMaP } \\
\text { (Lowlands) }\end{array}$ & -0.99 & $-33 \%$ & 0.67 & 0.68 & 0.31 \\
\hline $\begin{array}{c}\text { GSMaP } \\
\text { (Mountains) }\end{array}$ & -0.15 & $-10 \%$ & 0.62 & 0.76 & 0.44 \\
\hline $\begin{array}{c}\text { CMORPH } \\
\text { (Lowlands) }\end{array}$ & -0.5 & $-17 \%$ & 0.68 & 0.78 & 0.45 \\
\hline $\begin{array}{c}\text { CMORPH } \\
\text { (Mountains) }\end{array}$ & 0.20 & $12 \%$ & 0.59 & 0.79 & 0.54 \\
\hline $\begin{array}{c}\text { TRMM-3B42 } \\
\text { (Lowlands) }\end{array}$ & -0.05 & $-1 \%$ & 0.67 & 0.58 & 0.29 \\
\hline $\begin{array}{c}\text { TRMM-3B42 } \\
\text { (Mountains) }\end{array}$ & -0.01 & $0 \%$ & 0.61 & 0.64 & 0.38 \\
\hline $\begin{array}{c}\text { TRMM-3B42RT } \\
\text { (Lowlands) }\end{array}$ & 0.35 & $12 \%$ & 0.60 & 0.59 & 0.35 \\
\hline $\begin{array}{c}\text { TRMM-3B42RT } \\
\text { (Mountains) }\end{array}$ & 1.62 & $100 \%$ & 0.42 & 0.66 & 0.41 \\
\hline
\end{tabular}

* $\mathrm{RE}$ is abbreviation of relative error which is a ratio between mean error and mean precipitation of observations. 


\section{Discussion}

The analysis presented in this study provides a quantitative comparison between four satellite-based precipitation products and gauge based precipitation analysis dataset. It should be noted that topography obviously influences the accuracy of retrieval results [33,45,58,59]. Out results (Table 4) also supported this point well. For example, CMORPH underestimated precipitation in lowland regions while it overestimated precipitation in mountain regions. Many efforts have been devoted to evaluate precipitation products in Himalayan front region. Andermann et al. [66] suggested that satellite-based precipitation estimates might miss the changes of precipitation caused by topographic gradients in small scale. Krakauer et al., [67] also found that three precipitation datasets (GSMaP, CMORPH, PERSIANN-CCS) underestimated precipitation in mountain regions over Nepal. Howerver, evaluation of these satellite-based precipitation products were very limited over the Qinghai-Tibet Plateau. Therefore, it is necessary to investigate error characteristics in detail for popular satellite-based precipitation products over the Qinghai-Tibet Plateau with a very complex topography.

Moreover, the verification methods used in this study were traditional and widely employ to evaluate remote sensing precipitation estimates, such as bias, POD, FAR, etc. Development of methods for validation and uncertainty analysis are of great importance [59]. In recent year, several efforts were devoted to development various methods for validation of satellite-based precipitation estimates. To track the errors sources associated with the retrieval processes, Tian et al. [68] proposed an error decomposition scheme to separate the errors into three independent components. AghaKouchak et al. [62] investigated systematic and random error components of several satellite precipitation products. To investigate both the categorical and volumetric errors of remote sensing precipitation data, AghaKouchak [69] developed extended contingency table metrics to decompose the total bias into volumetric errors terms (e.g., biases) associated with categorical metrics (e.g., hit). A great deal of effort has been put to develop metrics for validation and uncertainty analysis, such as quantile bias [58], geometrical indices for evaluate precipitation patterns [70], and so on [71,72]. Gebremichael [73] summarized a framework for satellite rainfall product evaluation. Hence, it is necessary to investigate more detail information about error characteristics for these satellite-based precipitation datasets by using the geometrical and other metrics indices mentioned above. Another difficult challenge faced us is different scale of measurements and gridded precipitation data. Gauges provide the point measurement of precipitation. Gridded precipitation data is the spatial integrated data. It is also need to develop further validation methods to conquer this problem.

Furthermore, this study is focus on the performance of satellite-based precipitation products over the Chinese Mainland. There are two types precipitation dataset also should be included in evaluation studies. One is gridded precipitation dataset constructed based on the dense network of rain gauges and interpolation skill, such as APHRODITE [74]. Another type is precipitation dataset simulated by numerical weather prediction models and data assimilation technique, such as High Asia Reanalysis (HAR) $[75,76]$. These various gridded precipitation data sets were proved have many different strengths or imperfections [77,78]. It is worth to make a comparative analysis of various gridded precipitation data sets, including remote sensing, interpolated rain gauge data and simulated by numerical weather prediction models over the Chinese Mainland. 


\section{Conclusions}

Satellite-based precipitation products have provided global precipitation mapping in recent years. These products enabled a wide range of applications for hydrology, meteorology and land surface studies. Even though there have been many studies evaluating the performances of these products around the world, they have rarely been evaluated at either single grid scale or a continental scale over the Chinese Mainland. In this paper, four satellite-based precipitation products were evaluated by comparing with a gauge-based analysis of daily precipitation data over the Chinese Mainland during a four-year period from 2003-2006. The findings of this study included:

1. GSMaP and CMORPH underestimated precipitation amount. TRMM-3B42RT overestimated precipitation amount. TRMM-3B42 had the best estimation of precipitation amount in all four products. POD and FAR values of GSMaP lied in the middle of the values in all four datasets. CMORPH received the highest POD score, but its FAR value was the worst in all four datasets. In contrast, TRMM-3B42 had the lowest POD score, but its FAR score was also the lowest in all four datasets. POD and FAR values of TRMM-3B42RT were similar to TRMM-3B42.

2. Three satellite-based precipitation products (GSMaP, CMORPH and TRMM-3B42RT) had about 20\%-50\% more events than CMA-GRA across the range of $1-8 \mathrm{~mm} /$ day (low-intensity rainfall events). TRMM-3B42 underestimated the frequency of low-intensity rainfall events. The histograms of TRMM-3B42 and CMORPH aligned best with CMA-GRA in the range of $8-128 \mathrm{~mm} /$ day. TRMM-3B42RT overestimated the number of rainfall events in the range of 8-128 $\mathrm{mm} /$ day, whereas GSMaP had the fewest events among all four datasets across this range.

3. All satellite-based precipitation products performed well in capturing seasonal variability in precipitation. GSMaP underestimated precipitation all year round. Mean daily precipitation of the CMORPH and TRMM-3B42 generally agreed with the CMA-GRA. The TRMM-3B42RT dataset significantly overestimated precipitation each month. CC, POD and FAR indicate that satellite-based precipitation products performed better in summer than winter.

4. All satellite-based precipitation products performed well over most regions of China. They captured spatial patterns and magnitudes of rainfall for both individual rainfall systems and in daily mean precipitation determinations. GSMaP and CMORPH tended to underestimate precipitation amount over southern and southeastern China.TRMM-3B42RT overestimated precipitation over eastern Tibet and most of the northwestern arid and semiarid regions of the Chinese Mainland. TRMM-3B42 exhibited close alignment with gauge-based analyses. The spatial patterns of CC, POD and FAR for all satellite-based products were similar. All results indicate that the performance of the four satellite-based precipitation products over southeastern and wet region was better than in eastern Tibet and most of the regions in northwestern arid and semiarid regions of the Chinese Mainland.

\section{Acknowledgments}

This work is supported by the National Natural Science Foundation of China (Grant No. 41101375), the National Basic Research Program of China (973) (Grant No. 2010CB950902), Open Research Funding Program of KLGIS (Grant No.2011A10) and the Fundamental Research Funds for the Central 
Universities (Grant No. 2012LYB42 and 2013YB41). We appreciate greatly the work of the reviewers and editors.

\section{Author Contributions}

The concept of this study was conceived by Zhuoqi Chen, written by Yaxin Qin and Zhuoqi Chen, Yan Shen. Shupeng Zhang and Runhe Shi provided some of data.

\section{Conflicts of Interest}

The authors declare there are no conflicts of interest.

\section{References}

1. Gottschalck, J.; Meng, J.; Rodell, M.; Houser, P. Analysis of multiple precipitation products and preliminary assessment of their impact on global land data assimilation system land surface states. J. Hydrometeorol. 2005, 6, 573-598.

2. Tian, Y.; Peters-Lidard, C.D.; Choudhury, B.J.; Garcia, M. Multitemporal analysis of TRMM-based satellite precipitation products for land data assimilation applications. J. Hydrometeorol. 2007, 8, $1165-1183$.

3. Kidd, C.; Levizzani, V.; Turk, J.; Ferraro, R. Satellite precipitation measurements for water resource monitoring. J. Am. Water Resour. Assoc. 2009, 45, 567-579.

4. Buarque, D.C.; de Paiva, R.C.D.; Clarke, R.T.; Mendes, C.A.B. A comparison of amazon rainfall characteristics derived from TRMM, CMORPH and the Brazilian national rain gauge network. J. Geophys. Res. Atmos. 2011, 116, doi:10.1029/2011JD016060.

5. Kidd, C.; Bauer, P.; Turk, J.; Huffman, G.J.; Joyce, R.; Hsu, K.L.; Braithwaite, D. Intercomparison of high-resolution precipitation products over northwest Europe. J. Hydrometeorol. 2012, 13, 67-83.

6. Li, M.; Shao, Q. An improved statistical approach to merge satellite rainfall estimates and raingauge data. J. Hydrol. 2010, 385, 51-64.

7. Jameson, A.R.; Kostinski, A.B. Spurious power-law relations among rainfall and radar parameters. Q. J. R. Meteorol. Soc. 2002, 128, 2045-2058.

8. Behrangi, A.; Khakbaz, B.; Jaw, T.C.; AghaKouchak, A.; Hsu, K.; Sorooshian, S. Hydrologic evaluation of satellite precipitation products over a mid-size basin. J. Hydrol. 2011, 397, 225-237.

9. Kidd, C.; Huffman, G. Global precipitation measurement. Meteorol. Appl. 2011, 18, 334-353.

10. Kidd, C.; Levizzani, V. Status of satellite precipitation retrievals. Hydrol. Earth Syst. Sci. 2011, 15, 1109-1116.

11. Arkin, P.A.; Meisner, B.N. The relationship between large-scale convective rainfall and cold cloud over the western hemisphere during 1982-84. Mon. Weather Rev. 1987, 115, 51-74.

12. Ba, M.B.; Gruber, A. GOES multispectral rainfall algorithm (GMSRA). J. Appl. Meteorol. 2001, 40, 1500-1514.

13. Kummerow, C.; Hong, Y.; Olson, W.; Yang, S.; Adler, R.; McCollum, J.; Ferraro, R.; Petty, G.; Shin, D.B.; Wilheit, T. The evolution of the Goddard Profiling Algorithm (GPROF) for rainfall estimation from passive microwave sensors. J. Appl. Meteorol. 2001, 40, 1801-1820. 
14. Spencer, R.W.; Goodman, H.M.; Hood, R.E. Precipitation retrieval over land and ocean with the $\mathrm{SSM} / \mathrm{I}$ : Identification and characteristics of the scattering signal. J. Atmos. Ocean. Technol. 1989, 6, 254-273.

15. Wilheit, T.T.; Chang, A.T.C.; Chiu, L.S. Retrieval of monthly rainfall indices from microwave radiometric measurements using probability distribution functions. J. Atmos. Ocean. Technol. 1991, 8, 118-136.

16. Ebert, E.E.; Janowiak, J.E.; Kidd, C. Comparison of near-real-time precipitation estimates from satellite observations and numerical models. Bull. Am. Meteorol. Soc. 2007, 88, 47-64.

17. Huffman, G.J.; Adler, R.F.; Arkin, P.; Chang, A.; Ferraro, R.; Gruber, A.; Janowiak, J.; McNab, A.; Rudolf, B.; Schneider, U. The global precipitation climatology project (GPCP) combined precipitation dataset. Bull. Am. Meteorol. Soc. 1997, 78, 5-20.

18. Huffman, G.J.; Adler, R.F.; Rudolf, B.; Schneider, U.; Keehn, P.R. Global precipitation estimates based on a technique for combining satellite-based estimates, rain gauge analysis, and NWP model precipitation information. J. Clim.1995, 8, 1284-1295.

19. Turk, F.J.; Miller, S.D. Toward improved characterization of remotely sensed precipitation regimes with MODIS/AMSR-E blended data techniques. IEEE Trans. Geosci. Remote Sens. 2005, 43, 1059-1069.

20. Joyce, R.J.; Janowiak, J.E.; Arkin, P.A.; Xie, P. Cmorph: A method that produces global precipitation estimates from passive microwave and infrared data at high spatial and temporal resolution. J. Hydrometeorol. 2004, 5, 487-503.

21. Hsu, K.L.; Gao, X.; Sorooshian, S.; Gupta, H.V. Precipitation estimation from remotely sensed information using artificial neural networks. J. Appl. Meteorol. 1997, 36, 1176-1190.

22. Sorooshian, S.; Hsu, K.L.; Gao, X.; Gupta, H.V.; Imam, B.; Braithwaite, D. Evaluation of PERSIANN system satellite-based estimates of tropical rainfall. Bull. Am. Meteorol. Soc. 2000, 81, 2035-2046.

23. Hong, Y.; Hsu, K.L.; Sorooshian, S.; Gao, X. Precipitation estimation from remotely sensed imagery using an artificial neural network cloud classification system. J. Appl. Meteorol. 2004, 43, 1834-1853.

24. Huffman, G.J.; Adler, R.F.; Bolvin, D.T.; Nelkin, E.J.; Hossain, F.; Gebremichael, M. The TRMM multi-satellite precipitation analysis (TMPA). In Satellite Rainfall Applications for Surface Hydrology; Springer: Dordrecht, The Netherlands, 2010; pp. 3-22.

25. Huffman, G.J.; Bolvin, D.T.; Nelkin, E.J.; Wolff, D.B.; Adler, R.F.; Gu, G.; Hong, Y.; Bowman, K.P.; Stocker, E.F. The TRMM multisatellite precipitation analysis (TMPA): Quasi-global, multiyear, combined-sensor precipitation estimates at fine scales. J. Hydrometeorol. 2007, 8, 38-55.

26. Joyce, R.J.; Xie, P. Kalman filter-based CMORPH. J. Hydrometeorol. 2011, 12, 1547-1563.

27. Kubota, T.; Shige, S.; Hashizume, H.; Aonashi, K.; Takahashi, N.; Seto, S.; Takayabu, Y.N.; Ushio, T.; Nakagawa, K.; Iwanami, K.; et al. Global precipitation map using satellite-borne microwave radiometers by the GSMaP Project: Production and validation. IEEE Trans. Geosci. Remote Sens. 2007, 45, 2259-2275. 
28. Chen, Y.; Ebert, E.E.; Walsh, K.J.E.; Davidson, N.E. Evaluation of TRMM 3B42 precipitation estimates of tropical cyclone rainfall using PACRAIN data. J. Geophys. Res.: Atmos. 2013, 118, 2184-2196.

29. Chen, Y.; Ebert, E.E.; Walsh, K.J.E.; Davidson, N.E. Evaluation of TMPA 3B42 daily precipitation estimates of tropical cyclone rainfall over Australia. J. Geophys. Res.: Atmos. 2013, 118, 11966-11978.

30. Turk, F.J.; Arkin, P.; Ebert, E.E.; Sapiano, M.R.P. Evaluating high-resolution precipitation products. Bull. Am. Meteorol. Soc. 2008, 89, 1911-1916.

31. Tian, Y.; Peters-Lidard, C.D.; Adler, R.F.; Kubota, T.; Ushio, T. Evaluation of GSMaP precipitation estimates over the contiguous United States. J. Hydrometeorol. 2010, 11, 566-574.

32. Dinku, T.; Ceccato, P.; Grover-Kopec, E.; Lemma, M.; Connor, S.J.; Ropelewski, C.F. Validation of satellite rainfall products over East Africa's complex topography. Int. J. Remote Sens. 2007, 28 , 1503-1526.

33. Dinku, T.; Chidzambwa, S.; Ceccato, P.; Connor, S.J.; Ropelewski, C.F. Validation of high-resolution satellite rainfall products over complex terrain. Int. J. Remote Sens. 2008, 29, 4097-4110.

34. Dinku, T.; Ruiz, F.; Connor, S.J.; Ceccato, P. Validation and intercomparison of satellite rainfall estimates over Colombia. J. Appl. Meteorol. Climatol. 2010, 49, 1004-1014.

35. Xie, P.; Chen, M.; Yang, S.; Yatagai, A.; Hayasaka, T.; Fukushima, Y.; Liu, C. A gauge-based analysis of daily precipitation over East Asia. J. Hydrometeorol. 2007, 8, 607-626.

36. Sapiano, M.R.P.; Arkin, P.A. An intercomparison and validation of high-resolution satellite precipitation estimates with 3-hourly gauge data. J. Hydrometeorol. 2009, 10, 149-166.

37. Gosset, M.; Viarre, J.; Quantin, G.; Alcoba, M. Evaluation of several rainfall products used for hydrological applications over West Africa using two high-resolution gauge networks. Q. J. R. Meteorol. Soc. 2013, 139, 923-940.

38. Hong, Y.; Gochis, D.; Cheng, J.T.; Hsu, K.L.; Sorooshian, S. Evaluation of PERSIANN-CCS rainfall measurement using the NAME event rain gauge network. J. Hydrometeorol. 2007, 8, 469-482.

39. Koo, M.S.; Hong, S.Y.; Kim, J. An evaluation of the tropical rainfall measuring mission (TRMM) multi-satellite precipitation analysis (TMPA) data over South Korea. Asia-Pac. J. Atmos. Sci. 2009, 45, 265-282.

40. Moazami, S.; Golian, S.; Kavianpour, M.R.; Hong, Y. Comparison of PERSIANN and V7 TRMM Multi-satellite Precipitation Analysis (TMPA) products with rain gauge data over Iran. Int. J. Remote Sens. 2013, 34, 8156-8171.

41. Scheel, M.L.M.; Rohrer, M.; Huggel, C.; Villar, D.S.; Silvestre, E.; Huffman, G.J. Evaluation of TRMM Multi-satellite Precipitation Analysis (TMPA) performance in the Central Andes region and its dependency on spatial and temporal resolution. Hydrol. Earth Syst. Sci. 2011, 15, 2649-2663.

42. Sohn, B.J.; Han, H.J.; Seo, E.K. Validation of satellite-based high-resolution rainfall products over the Korean Peninsula using data from a dense rain gauge network. J. Appl. Meteorol. Climatol. 2009, 49, 701-714.

43. Shen, Y.; Xiong, A.; Wang, Y.; Xie, P. Performance of high-resolution satellite precipitation products over China. J. Geophys. Res.: Atmos. 2010, 115, doi:10.1029/2009JD012097. 
44. Mehran, A.; AghaKouchak, A. Capabilities of satellite precipitation datasets to estimate heavy precipitation rates at different temporal accumulations. Hydrol. Process. 2014, 28, 2262-2270.

45. Li, X.; Zhang, Q.; Xu, C.Y. Assessing the performance of satellite-based precipitation products and its dependence on topography over Poyang Lake basin. Theor. Appl. Climatol. 2014, 115, 713-729.

46. Li, Z.; Yang, D.; Hong, Y. Multi-scale evaluation of high-resolution multi-sensor blended global precipitation products over the Yangtze River. J.. Hydrol. 2013, 500, 157-169.

47. Yong, B.; Ren, L.L.; Hong, Y.; Wang, J.H.; Gourley, J.J.; Jiang, S.H.; Chen, X.; Wang, W. Hydrologic evaluation of Multisatellite Precipitation Analysis standard precipitation products in basins beyond its inclined latitude band: A case study in Laohahe basin, China. Water Resour. Res. 2010, 46, doi:10.1029/2009WR008965.

48. Yu, Z.; Yu, H.; Chen, P.; Qian, C.; Yue, C. Verification of tropical cyclone-related satellite precipitation estimates in mainland China. J. Appl. Meteorol. Climatol. 2009, 48, 2227-2241.

49. Zhou, T.; Yu, R.; Chen, H.; Dai, A.; Pan, Y. Summer precipitation frequency, intensity, and diurnal cycle over China: A comparison of satellite data with rain gauge observations. J. Clim. 2008, 21, 3997-4010.

50. Chen, M.; Shi, W.; Xie, P.; Silva, V.B.S.; Kousky, V.E.; Wayne Higgins, R.; Janowiak, J.E. Assessing objective techniques for gauge-based analyses of global daily precipitation. J. Geophys. Res.: Atmos. 2008, 113, doi:10.1029/2007JD009132.

51. Xie, P.; Xiong, A.Y. A conceptual model for constructing high-resolution gauge-satellite merged precipitation analyses. J. Geophys. Res.: Atmos. 2011,116, doi:10.1029/2011JD016118.

52. Okamoto, K.; Ushio, T.; Iguchi, T.; Takahashi, N.; Iwanami, K. The global satellite mapping of precipitation (GSMaP) project. In Proceedings of the 2005 IEEE International Geoscience and Remote Sensing Symposium, 2005, IGARSS '05, Seoul, Korea, 25-29 July 2005; Volume 5, pp. 3414-3416.

53. Aonashi, K.; Liu, G. Passive microwave precipitation retrievals using TMI during the Baiu period of 1998. Proc. SPIE 2000, 4152, doi:10.1117/12.410602

54. Ushio, T.; Sasashige, K.; Kubota, T.; Shige, S.; Okamoto, K.; Aonashi, K.; Inoue, T.; Takahashi, N.; Iguchi, T.; Kachi, M. A Kalman filter approach to the Global Satellite Mapping of Precipitation (GSMaP) from combined passive microwave and infrared radiometric data. J. Meteorol. Soc. Jpn. 2009, 87, 137-151.

55. Negri, A.J.; Xu, L.; Adler, R.F. A TRMM-calibrated infrared rainfall algorithm applied over Brazil. J. Geophys. Res.: Atmos. 2002, 107, doi:10.1029/2000JD000265.

56. Romilly, T.G.; Gebremichael, M. Evaluation of satellite rainfall estimates over Ethiopian river basins. Hydrol. Earth Syst. Sci. 2011, 15, 1505-1514.

57. Ebert, E. Methods for verifying satellite precipitation estimates. In Measuring Precipitation from Space; Levizzani, V., Bauer, P., Turk, F.J., Eds.; Springer: Dordrecht, The Netherlands, 2007; Volume 28, pp. 345-356.

58. AghaKouchak, A.; Behrangi, A.; Sorooshian, S.; Hsu, K.; Amitai, E. Evaluation of satellite-retrieved extreme precipitation rates across the central United States. J. Geophys. Res.:Atmos. 2011, 116, doi:10.1029/2010JD014741. 
59. Sorooshian, S.; AghaKouchak, A.; Arkin, P.; Eylander, J.; Foufoula-Georgiou, E.; Harmon, R.; Hendrickx, J.M.H.; Imam, B.; Kuligowski, R.; Skahill, B.; et al. Advancing the remote sensing of precipitation. Bull. Am. Meteorol. Soc. 2011, 92, 1271-1272.

60. Gebregiorgis, A.S.; Hossain, F. Understanding the dependence of satellite rainfall uncertainty on topography and climate for hydrologic model simulation. IEEE Trans. Geosci. Remote Sens. 2013, 51, 704-718.

61. Nasrollahi, N.; Hsu, K.; Sorooshian, S. An artificial neural network model to reduce false alarms in satellite precipitation products using MODIS and CloudSat observations. J. Hydrometeorol. 2013, 14, 1872-1883.

62. AghaKouchak, A.; Mehran, A.; Norouzi, H.; Behrangi, A. Systematic and random error components in satellite precipitation data sets. Geophys. Res. Lett. 2012, 39, doi:10.1029/2012GL051592.

63. McCollum, J.R.; Gruber, A.; Ba, M.B. Discrepancy between gauges and satellite estimates of rainfall in equatorial Africa. J. Appl. Meteorol. 2000, 39, 666-679.

64. Beighley, R.E.; Ray, R.L.; He, Y.; Lee, H.; Schaller, L.; Andreadis, K.M.; Durand, M.; Alsdorf, D.E.; Shum, C.K. Comparing satellite derived precipitation datasets using the Hillslope River Routing (HRR) model in the Congo River Basin. Hydrol. Process. 2011, 25, 3216-3229.

65. Giovannettone, J.P.; Barros, A.P. Probing regional orographic controls of precipitation and cloudiness in the central Andes using satellite data. J. Hydrometeorol. 2009, 10, 167-182.

66. Andermann, C.; Bonnet, S.; Gloaguen, R. Evaluation of precipitation data sets along the Himalayan front. Geochem. Geophys. Geosyst. 2011, 12, doi:10.1029/2011GC003513.

67. Krakauer, N.Y.; Pradhanang, S.M.; Lakhankar, T.; Jha, A.K. Evaluating satellite products for precipitation estimation in mountain regions: A case study for Nepal. Remote Sens. 2013, 5, 4107-4123.

68. Tian, Y.; Peters-Lidard, C.D.; Eylander, J.B.; Joyce, R.J.; Huffman, G.J.; Adler, R.F.; Hsu, K.L.; Turk, F.J.; Garcia, M.; Zeng, J. Component analysis of errors in satellite-based precipitation estimates. J. Geophys. Res.: Atmos. 2009, 114, doi:10.1029/2009JD011949.

69. AghaKouchak, A.; Mehran, A. Extended contingency table: Performance metrics for satellite observations and climate model simulations. Water Resour. Res. 2013, 49, 7144-7149.

70. AghaKouchak, A.; Nasrollahi, N.; Li, J.; Imam, B.; Sorooshian, S. Geometrical characterization of precipitation patterns. J. Hydrometeorol. 2011, 12, 274-285.

71. Hong, Y.; Hsu, K.L.; Moradkhani, H.; Sorooshian, S. Uncertainty quantification of satellite precipitation estimation and monte carlo assessment of the error propagation into hydrologic response. Water Resour. Res. 2006, 42, doi:10.1029/2005WR004398.

72. AghaKouchak, A.; Nasrollahi N.; Habib, E. Accounting for uncertainties of the TRMM satellite estimates. Remote Sens. 2009, 1, 606-619.

73. Gebremichael, M. Framework for satellite rainfall product evaluation. In Rainfall: State of the Science; AGU: Washington, DC, USA, 2010; Volume 191, pp. 265-275.

74. Yatagai, A.; Kamiguchi, K.; Arakawa, O.; Hamada, A.; Yasutomi, N.; Kitoh, A. APHRODITE: Constructing a long-term daily gridded precipitation dataset for Asia based on a dense network of rain gauges. Bull. Am. Meteorol. Soc. 2012, 93, 1401-1415. 
75. Maussion, F.; Scherer, D.; Finkelnburg, R.; Richters, J.; Yang, W.; Yao, T. WRF simulation of a precipitation event over the Tibetan Plateau, China-An assessment using remote sensing and ground observations. Hydrol. Earth Syst. 2011, 15, 1795-1817.

76. Maussion, F.; Scherer, D.; Mölg, T.; Collier, E.; Curio, J.; Finkelnburg, R. Precipitation seasonality and variability over the Tibetan Plateau as resolved by the High Asia Reanalysis. J. Clim. 2014, 27 , 1910-1927.

77. Duethmann, D.; Zimmer, J.; Gafurov, A.; Güntner, A.; Kriegel, D.; Merz, B.; Vorogushyn, S. Evaluation of areal precipitation estimates based on downscaled reanalysis and station data by hydrological modelling. Hydrol. Earth Syst. Sci. 2013, 17, 2415-2434.

78. Palazzi, E.; von Hardenberg, J.; Provenzale, A. Precipitation in the Hindu-Kush Karakoram Himalaya: Observations and future scenarios. J. Geophys. Res.: Atmos. 2013, 118, 85-100.

(C) 2014 by the authors; licensee MDPI, Basel, Switzerland. This article is an open access article distributed under the terms and conditions of the Creative Commons Attribution license (http://creativecommons.org/licenses/by/4.0/). 